\title{
サルにかかわる大問題
}

\section{Monkey business}

\section{人間の世界で起きる児童虐待に関して、霊長類研究ははたして何かの役に立つのだろうか。本コ ラムでは、Nature のオンラインニュース担当記者 Michael Hopkin が霊長類研究をめぐる問 題を考えた。}

\section{doi:10.1038/news050627-11/30 June 2005}

Michael Hopkin

類人猿などのサル、ヒトの仲間である 霊長類は、時に人類自身の姿を知るた めの手がかりを映しだす鏡となる。配 偶行動や種族組織、それに家族生活と いう場でサルがどのような行動をとる か。こういった研究から得られること は多い。しかし、だからといってその 種の研究を突き詰めるために、サルに 苦痛を強いる必要は断じてない。

最近 Proceedings of the National Academy of Sciences に発表された研究 ${ }^{1}$ はアカゲ ザルの児童虐待に光を当てたものだっ たが、その裏の目的は人間の児童虐待 の解決にある。こうした虐待は、アカ ゲザルでも人間でも自然に発生してい る。アカゲザルの子の 5〜 10\% は、程 度の差はあれ、かむ、押しつぶす、投 げ飛ばすなどの身体的攻撃を母親から 受けている。

人間でもアカゲザルでも、児童虐待 は次の世代に受け継がれるという性質 がある。虐待をする人間のおよそ70\% は、自身も子どものときに同じ目にあ っていたと推定されている。このこと から生物学者は、こうした傾向は経験 によるのか、あるいは遺伝子によるの かという問題を考えるようになった。 つまり、子を虐待するという行為は、 後天的に獲得されたものなのか先天的 なものなのか、という問題だ。

この疑問を解明しようと、シカゴ大学 の生物学者 Dario Maestripieri はヤー キーズ国立霊長類研究センター (米国 ジョージア州ローレンスビル) でアカ ゲザルの研究を行った。Maestripieri は、虐待をする実母をもつ子ザルと虐 待をしない実母をもつ子ザルを複数、 それぞれ母親から引き離し、別の雌ザ ルに育てさせた。ここで養母に選ばれ た雌ザルには、過去に虐待をしたこと があるものも、そうでないものもいた。
別の子ザルは実の母親のところにとど めたが、ここでも虐待をする母ザルと しない母ザルを用いた。こうしてあら ゆる組み合わせを網羅することで、子 に対して優しく接するかどうかは遺伝 的素因によるものなのか、経験による ものなのかが調べられた。

\section{母の愛}

その結果、虐待をする母ザルに育てら れた子ザル 16 匹のうち 9 匹は、自ら の子を虐待するサルに育った。虐待を しない母ザルに育てられた子ザルは、 親になっても虐待をしなかった。唯一 結果を左右したのは、どのように育て られたかということだった。実の母親 が虐待をするかどうかは、まったく結 果に影響しなかった。

小規模ではあるがこの試験は、子へ の虐待傾向が遺伝子ではなく幼時の経 験によって形成されることを意味して いる。そのまますぐに人間の家族に当 てはめられがちな結論だ。

しかし、人間の挙動に関する疑問を 解明するのにサルを用いるのが、最適 な方法なのだろうか。さらに、こうし た知見 (実験結果) があれば、人間社会 における児童虐待を解決できるのだろ うか。私はいずれもそうは思わない。

この研究の意図そのものは称賛され てよいものだろう。だが、いくら虐待 が自然に発生するものとはいえ、苦痛 を与える可能性がきわめて高い雌ザル のもとに子ザルを置くのは間接的な残 虐行為だといってもよいと思う。ヤー キーズの施設は国際実験動物管理認定 協会の完全認定を受けており、この分 野の専門家の目には、実験が倫理的に 適切だと映っている。しかし、その考 えには賛同しかねる。

\section{適切な方法か？}

人間での虐待の問題を解明する方法は ほかにある。虐待が後天的なものか先 天的なものかという問題は、実際に虐 待を予防するうえでは役に立たない。 それよりも、しかるべき社会的ケアの ネットワークを確立しておくことのほ うがはるかに重要である。また、仮に そうした問題が重要性をもっていると しても、研究材料としては養育施設が もつ大量のデータにまず目を向けるべ きではないか。

米国はこれまで、常に実験的霊長類 研究の拠点となってきた。欧州をはじ めとして多くの国では、この種の研究 の承認はなかなか得られない。研究用 動物に関する倫理は、研究で得ること が期待される知識に対し、与える苦痛 が正当化可能なものであるかどうかを 基本とするべきである。

実験的研究では苦痛が避けられない 場合が多く、それは人間の場合でも同 じだ。しかし、動物の子から親による 養育を意図的に奪う研究には心の痛み を覚える。1960 年代には、とがった細 長い金属でできた作り物の母親のもと に子ザルを置き、やすらぎを求めて冷 たいかたまりに寄り添おうとする子ザ ルを観察する研究が行われた。子が親 の愛を追求することを知るための霊長 類研究など必要だったのだろうか。

あらゆる動物にはさまざまな知覚力 があり、科学研究のために動物を使用 する場合は、その倫理性が考慮される ベきである。感情的な苦痛を真に感じ る能力をもつ霊長類の場合、今回のよ うな科学的介入はとくに最小限にとど めるべきと考える。

1. Maestripieri D. Proc. Natl Acad. Sci. USA, 102. 9726 9729(2005) 